\title{
EXPRESSIONS OF RELATIONAL POWER IN NATO DISCOURSE: COOPERATION WITH FORMER ADVERSARIES
}

\author{
Isabela Anda DRAGOMIR \\ "Lucian Blaga" University of Sibiu, Romania \\ isabela.dragomir@ulbsibiu.ro
}

\begin{abstract}
The dissolution of the Soviet Empire in 1991 has challenged the North Atlantic Treaty Organization to grapple with an issue that had been avoided and postponed during the Cold Warhow to give specific and practical content to the Alliance's long-standing vision of a peaceful political order in Europe. This paper examines the galvanizing role of language in forging a solid discourse aimed at initiating and consolidating cooperation between the Alliance and its former adversaries in the aftermath of the Soviet Union's collapse. Drawing on discourse analysis as a method of qualitative investigation, the present linguistic exploration of military discourse focuses on a number of NATO official documents that reify the Alliance's determination to contribute to the construction of a more secure transatlantic environment.
\end{abstract}

\section{Keywords: NATO discourse, cooperation, discourse analysis, relational power}

\section{Introduction}

The three core strategic tasks of the North Atlantic Treaty Organization (NATO) in the $21^{\text {st }}$ century are collective defense, crisis management and cooperative security. They all encompass the Alliance's ideological ambition to become a security institution that promotes cooperation by being actively and intentionally open to the world around and by redefining itself as an organization which embodies relational power. At the end of the $20^{\text {th }}$ century, as the East European communist regimes of the Warsaw Pact were swept out by the democratic revolutions and the Soviet Union collapsed under its own weight, NATO was obliged to cope with a new architecture of transatlantic security. To this aim, the Alliance transformed itself from a strictly collective defense alliance to an organization that embraced the much broader and more demanding functions of a collective security institution. One of the mechanism of adaptation was NATO's explicit intention to establish cooperation with its former adversaries.

\section{The Discourse of Relational Power}

David Yost (1998) considers that the phrase "cooperation with former adversaries" refers to "the magnitude of the more ambitious and demanding of the Alliance's new roles" [1]. Indeed, in the aftermath of the Cold War, NATO has repeatedly expressed a commitment to bring its contribution to building a more peaceful political order in Europe as a whole. In order to achieve this goal, the Alliance has set up a number of institutions through which to mitigate cooperation on security issues between NATO and former adversaries or other non-NATO countries. Among these institutions, the North Atlantic Cooperation Council, replaced by the Euro-Atlantic Partnership Council in May 1997, the Partnership for Peace and the NATO-Russia Permanent Joint Council are the most notable. The cooperation was 
cemented through a series of authoritative declarations, underlining NATO's selfassigned role as an "agent of change" throughout Europe.

NATO's ambition to contribute to a longstanding vision of a peaceful political order in Europe was initially expressed in the Harmel Report (1967): "The ultimate political purpose of the Alliance is to achieve a just and lasting peaceful order in Europe, accompanied by appropriate security guarantees" [2]. At the NATO summit held in London, in July 1990, the first to be organized after the collapse of the East European communist governments, the allies expressed their determination to maintain the peace, and invested in NATO's ability to construct a Europe "whole and free". In the words of the London Declaration, this vision is made possible through cooperation, unity and the promotion of shared values, all of which are the pillars of relational power. "We need to keep standing together, to extend the long peace we have enjoyed these past four decades. Yet our alliance must be even more an agent of change. It can help build the structures of a more united continent, supporting security and stability with the strength of our shared faith in democracy, the rights of the individual and the peaceful resolution of disputes" [3].

Furthermore, in London, NATO announced that it would embark on a mission aimed at reaching out "to the countries of the East which were our former adversaries in the Cold War, and extend to them the hand of friendship" [4]. In practical terms, it translated into military contacts between NATO and the Warsaw Pact states and a joint declaration in which the two parties affirmed that they were "no longer adversaries".

These ideas were reiterated in the 1991 Strategic Concept, which uses a similar formulation to recall that "the Alliance has worked since its inception for the establishment of a just and lasting peaceful order in Europe" [5]. While the initial reference to this goal in the Harmel Report was not detailed in terms of the specific means of achieving it, and was rather a generally assumed task of the Alliance, the 1991 strategic document adds an important aspect: that the vision of a peaceful Europe shall be achieved by pursuing "the development of co-operative structures of security for a Europe whole and free" [6]. The formulation of the Strategic Concept emphasizes that one of the Alliance's fundamental tasks is "to provide one of the indispensable foundations for a stable security environment in Europe, based on the growth of democratic institutions and commitment to the peaceful resolution of disputes, in which no country would be able to intimidate or coerce any European nation or to impose hegemony through threat or use of force" [7].

This vision was extended five years later, when the North Atlantic Council advocated the construction of "cooperative European security structures which extend to countries throughout the whole Europe without excluding anyone or creating diving lines" [8]. With these tasks on its agenda, NATO assumed the role of unifying nations throughout Europe through the display of relational power in both discourse and practice.

This galvanizing exercise was also supported by U.S. policy. In February 1997, U.S. Secretary of State Madeleine Albright remarked that it was time for the new NATO to do the same things for the east that it had done for the west after World War II. In Albright's own words "the fundamental role of our policy is to build, for the very first time, a peaceful, democratic and undivided transatlantic community" [9]. The assumed task of the Alliance was to extend eastward - towards Central Europe and the states of the former USSR - and to offer the Eastern part of the continent the peace and prosperity that Western Europe had benefited from in the last fifty years. 
Adopted in Paris in May 1997, the NATORussia Founding Act encompasses a greater vision, with goals for extended collective security in the Euro-Atlantic region. "NATO and Russia, based on an enduring political commitment undertaken at the highest political level, will build together a lasting and inclusive peace in the EuroAtlantic area on the principles of democracy and cooperative security... Proceeding from the principle that the security off all states in the Euro-Atlantic community is indivisible, NATO and Russia will work together to contribute to the establishment in Europe of a common and comprehensive security based on the allegiance to shared values, commitments and norms of behavior in the interest of all states...NATO and Russia will seek the widest possible cooperation among participating States of the OSCE with the aim of creating in Europe a common space of security and stability, without dividing lines or spheres of influence limiting the sovereignty of any state" [10].

The language of the illustrated documents is extremely straightforward and repetitive, with great emphasis laid on the words "security" and "stability" throughout the formulations. The syntactic linchpin of the cooperation between NATO and Russia is the usage of the prospective tense employed as to direct the future actions of the two actors towards a common practice to be equally assumed by both. "Democracy", "indivisibility" and "shared values", norms and attitudes are abstract concepts that populate the discourse with the aim of ideologically fundamenting the exercise of cooperation. In the text of The Founding Act on Mutual Relations, Cooperation and Security between the North Atlantic Treaty Organization and the Russian Federation, the usage of augmentative markers, such as "wider" and "comprehensive", underline the importance and the extent of cooperation, which is to be achieved through all means. The key concept to be identified in the last three mentioned examples is, without any doubt, that of "indivisibility". Cooperation is efficient and conceptually valid as long as it does not affect the sovereignty of any state and given that it functions on the principle of an "undivided community" without creating "diving lines".

Such a goal is achievable through the creation of institutions and partnership programs that function under a set of preestablished rules and base practice on commonly agreed values and norms. The North Atlantic Cooperation Council (NAAC) and the Partnership for Peace (PfP) represent the Alliance's primary efforts to institutionalize cooperative relations with the former Warsaw Pact states and other non-NATO countries in the Euro-Atlantic region. Starting from the premise that discourse is the linguistic locus of institutional expression and communication, I consider relevant in this context to briefly mention the institutions tasked with promoting the Alliance's cooperation goals and to analyze their activities and rhetoric in so far as it serves the purpose of illustrating their contribution to the exercise of relational power.

\subsection{The North Atlantic Cooperation Council}

The North Atlantic Cooperation Council (henceforth referred to as NAAC) was the Alliance's initial attempt to outstrip military and diplomatic contacts with the states of the Warsaw Pact (formally disbanded in 1991) and to develop, as stated in the Rome Declaration "a more institutional relationship of consultation and cooperation on political and security issues" with Bulgaria, Czechoslovakia, Estonia, Hungary, Latvia, Lithuania, Poland, Romania and the Soviet Union [11]. The ministers of foreign affairs from all the former Warsaw Pact states were invited to meet their NATO counterparts in December 1991, a date which marked the first meeting of the NAAC.

With accent placed on "cooperation" and "consultation", one of the aspects discussed 
at the first NAAC meeting was that its members would reconvene every year at the foreign minister level, and every other month at ambassadorial level, with additional meetings depending on the circumstances. Under the auspices of NATO committees, the NAAC members decided to hold other meetings and tackle security-related issues such as "defense planning, conceptual approaches to arms control, democratic concepts of civilmilitary relations, civil-military coordination of air traffic management, and the conversion of defense production to civilian purposes" [12].

NAAC activities consisted of meetings seminars, workshops, colloquiums, conferences etc. The Council encompassed sixteen NATO countries and twenty-two "former adversaries". It was composed of all the member states of the Warsaw Pact, including the successor nations of the former USSR, as well as Slovakia and the Czech Republic. Some other states, such as Austria, Finland, Slovenia, Sweden, and Switzerland were given observer status in NAAC.

Given that the Alliance is an intergovernmental organization, national views may sometimes be divergent and consequently need to be reconciled. However, the NAAC was relatively uncontroversial. With the exception of France, which initially opposed the creation of the Council, given the fact that French ministers of defense had not participated in meetings with their NATO counterparts since 1966, when France pulled out from the integrated military command structure, all the other members seem to have found common ground when discussing topics related to arms control verification, peacekeeping, scientific and environmental cooperation, and the conversion of defense industries. With the subsequent development of the Partnership for Peace (PfP), NAAC was replaced in May 1997 by the Euro-Atlantic Partnership Council, a wider organization including all PfP and NAAC participants.

\subsection{Partnership for Peace}

In January 1994, at the Summit held in Brussels, NATO announced its intention to "launch an immediate and practical program that will transform the relationship between NATO and participating states" [13]. It was a renovating program intended to go beyond military cooperation and diplomatic dialogue, and aimed at forging a real partnership - the Partnership for Peace. The North Atlantic Council declaration continues: "We invite the other states participating in the NAAC, and other OSCE countries able and willing to contribute to this program, to join us in this Partnership" [14]. The invitation clearly annuls the "us" versus "others" dichotomy and bridges the affiliation gap between NATO and nonNATO states. Although the text of the document does not explicitly mention any criteria the potential PfP candidates need to meet, the two adjectives used to characterize the prospective members of this program are indicative of the requirements the Alliance is targeting: the candidates must be "able", in terms of capabilities and "willing" in so far as their commitment to the values of the Alliance is concerned. The document states the goal of the partnership, which aims "to expand and intensify political cooperation throughout Europe, increase stability, diminish threats to peace and build strengthened relationships by promoting the spirit of practical cooperation and commitment to democratic principles that underpin our Alliance" [15]. The enumeration of action verbs illustrates the dynamics of the ambitious tasks envisaged by the PfP, seen as strong reality and facts. The choice of the present infinitive is, however, more than a mere aspect of anchoring the action within a non-specific timeframe. It clearly impacts on the cognitive representation of the action, as being true, relevant and significant. Furthermore, the "by" phrase is used so as to indicate the manner in which 
these activities must be performed, thus tying institutional practice to the ideology promoted by NATO. The lexical binders of this particular discourse are, again, represented by the repetition of nouns carrying the same semantic value: "cooperation", "commitment", "relationships".

The Partnership for Peace program and the rhetoric associated with it are illustrative for the referent and expert dimensions of power assumed by NATO in this context. The Alliance has been the sponsor or senior partner in PfP in that it was NATO that established the purview of the program, including the list of activities available for inclusion therein. The major powers in the Alliance acted as points of reference for the smaller powers in Europe, who are perceived as valuable partners, albeit not ready to become full members yet.

The next logical question to be asked is in what manner does the scope of PfP integrate within the broader framework of the Alliance? The language used to define the purposes of this partnership resembles closely, as if copied, to the formulation in Article 4 of the North Atlantic Treaty: "NATO will consult with any active participant in the Partnership if that partner perceives a direct threat to its territorial integrity, political independence or security" [16]. The text of the Article 4 of the North Atlantic Treaty reads: "The Parties will consult together whenever, in the opinion of any of them, the territorial integrity, political independence or security of any of the Parties is threatened" [17]. A number of key concepts are identically formulated in both documents: "territorial integrity", "political independence" and "security", representing three of the major ideological pillars on which the Alliance was initially built. A further step taken towards the consolidation of the values inherent in NATO's ideology and their alignment with the goals of the program consists in the agenda of the PfP, which included the promotion of standardization, especially in what regards the operational language used by the Alliance. To this aim, more than eight hundred NATO standardization documents were transferred to the Partners, containing references to concepts of operation, standard operating procedures and military doctrine [18].

\section{Conclusions}

History has demonstrated that great powers have typically sought to manage international order, from enforcing traditional balance-of-power arrangements to adopting more elaborate designs of collective security. Against the background of a sometimes unreliable system of collective security, the major powers will always look for new arrangements to protect their national interests. In the aftermath of the Soviet Union's demise, NATO embarked on a grand endeavor, that of creating something better than the balance of power as the new architecture of transatlantic security.

This paper aimed at demonstrating that language is an essential tool of empowering institutions to recognize and address important issues, find common grounds for action, establish relations and implicitly build a shared sense of identity and participation. NATO cooperation programs were made possible and effective not only through institutional practices, but also with the help of well-structured and targeted mediated discourse, utilized in order to galvanize collective efforts toward a common goal, that of resolving security challenges stemming from the everchanging global balance of power.

\section{References}

[1] David Yost, NATO Transformed. The Alliance's New Roles in International Security, Washington, D.C.: United States Institution of Peace Press, 1998, p. 91. 
[2] The Future Tasks of the Alliance, Report of the Council, annex to the Final Communique of the Ministerial Meeting, December 13-14, 1967, in Texts of Final Communiqués, p. 200.

[3] North Atlantic Council, London Declaration on a Transformed North Atlantic Alliance, July

6, 1990, para. 8.

[4] Ibid., para 6.

[5] 1991 Strategic Concept, para. 16.

[6] Ibid., para 19.

[7] Ibid., para 21.

[8] North Atlantic Council Communiqué, December 10, 1996, para. 4.

[9] Madeleine Albright, Enlarging NATO, The Economist, February 15, 1997, p. 22.

[10] NATO-Russia Founding Act on Mutual Relations, Cooperation and Security between the North Atlantic Treaty Organization and the Russian Federation, 1997, pp. 2-3.

[11] North Atlantic Council, Rome Declaration on Peace and Cooperation, November 8, 1991, para. 11.

[12]North Atlantic Cooperation Council, Statement on Dialogue, Partnership and Cooperation, December 20, 1991, para. 4.

[13] North Atlantic Council, The Brussels Summit Declaration, January 11, 1994, para. 13.

[14] Ibid.

[15] Ibid., para. 19.

[16] Ibid.

[17] Washington Treaty, Art. 4.

[18] Nick Williams, Partnership for Peace: Permanent Fixture or Declining Asset?, Survival 38 (Spring 1996), pp. 103-104. 